not as belonging to any particular race or age. Civilisation only deepens our need of Him.

Since so much has been done in fulfilment of Christ's words, we may be confident that all nations will at last be brought under His sway. It is ours to help on the work. We are included in this charge. Some may have special duties in preaching, but we have each to announce forgiveness on repentance to the classes of the community around us.

\title{
Eontributions and Comment
}

\section{Qunecoota Oroníentia. ${ }^{1}$}

THIS is a most interesting number of the Anecdota Oxoniensia. It contains the following fragments of Palestinian Syriac:-Exodus xxviii. I-I $2 a$; Wisdom ix. $8 b-x .2 ; 3$ Kings ii. $10 b-15 a$ and ix. $4,5^{a}$; Job xxii. $3^{b-12}$; with some fragments of Ancient Homilies. It is accompanied with three Facsimiles. The biblical texts are fragments of the old Palestinian Syriac version of the Holy Scriptures. $A$ full list of the remains of that version as yet known has been given by Mr. Gwilliam in an earlier part (part v.) of these Anecdota, issued in 1893 , together with an account of the literature on the subject. That part contained five fragments, four of which were New Testament passages, and one containing a few verses of Numbers iv. and v. In the present part there are important 'Additions and Corrections' of the readings adopted in the earlier part. The excursus in question is the work of Mr. Stenning, aided by Mr. Gwilliam. These two scholars have also a valuable excursus on Palestinian Handwriting, and on the dates to which these fragments severally ought to be assigned, which appears to be somewhat about the eighth or ninth centuries.

All the fragments are printed in a splendid Estrangela Syriac type, accompanied by an English translation and critical notes. Forms peculiar to Palestinian Syriac are duly pointed out in the notes, and these notes are likely to prove of considerable importance by and by. They show that the discovery of more of this version will probably

\footnotetext{
1 Anecdota Oxonicnsia. Semitic Series, vol. i. part ix. Biblical and Patristic Relics of the Palestinian Syriac Literature. From MSS. in the Bodleian Library and in the Library of St. Catharine on Mount Sinai. Edited by G. H. Gwilliam, B.D., Fellow of Hertford College, Oxford; F. Crawford Burkitt, M.A., Trinity College, Cambridge; and John F. Stenning, M.A., Senior Demy of Magdalen College, Oxford. Oxford : Clarendon Press, I 96.
}

throw not a little light upon both New Testament and Old Testament textual criticism, especially when considered in connexion with the text of the LXX. The Palestinian Syriac version seems to have been translated from the I.XX, and not directly from the Hebrew. The influence of the Hebrew original is, however, tolerably clear in some passages, while the text of the LXX, from which the translation was made, appears to have differed considerably from that exhibited in any MS. yet extant. The closeness with which in some places the Lucianic recension of the LXX is adhered to, gives a peculiar value to these fragments.

The passages of Scripture quoted in the 'Ancient Homilies' appear not to have been taken from the Palestinian Version, although the Syriac of those fragments is certainly Palestinian. The author of the 'Homilies' in question seems to have quoted from memory, which may account partially for the fact noticed; and as we do not know whether the 'Homilies' may not have been modified in transmission, we cannot be certain how far the biblical quotations may have been modified by the copyist.

It should be noted that the two first fragments contained in this volume were procured for the Bodleian Library by Professor Sayce. These were discovered with other writings beneath a synagogue in Cairo, when the site was cleared to make room for some new buildings. These fragments are palimpsests, and have been carefully edited by $\mathrm{Mr}$. Gwilliam. The shorter fragments of 3 Kings and Job were found in MSS. in the Library of St. Catharine on Mount Sinai, at the time when the party composed of Mrs. Lewis, Mrs. Gibson, Professor Rendell Harris, Mr. Stenning, Mr. Burkitt, with the late Professor R. B. Bensly of Cambridge, and his wife, visited and worked at the Library of that convent.

Mrs. Bensly, though not herself a Syriac scholar, has the merit of having discovered these interesting 
Syriac Homilies half hidden in the binding of a modern Arabic MS. She reported her discovery to her husband, who at once recognised its value, and obtained the permission of the librarian of the convent to examine the binding, and detach the leaves which were embedded therein. Mrs. Bensly then made a careful transcript of those leaves, and got photographs of them. Mrs. Lewis assisted in this part of the work. The Syriac text of the Homilies has been carefully edited by Mr. Burkitt. It occupies twenty-four pages, while the English translation and notes furnished by the same scholar runs to about the same extent.

Fragmentary though it is, this part of the volume is of very peculiar interest. The copy of the Homilies is probably not later than the ninth century, and may be even older, while the Homilies themselves may be of much greater antiquity. They contain an interesting exegesis of the words addressed by our Lord to Peter when He publicly restored that apostle to his office, as recorded in John xxi. The 'sheep' are expounded to mean 'the men,' the 'ewes' to denote 'the women,' and the 'lambs' 'the boys and girls.' In illustration of the importance of the priest's office in the Church, and the honour due to it, reference is made to the narrative in Numbers of Miriam murmuring against Moses, and to the account of the Deluge in Genesis. In the latter case, particular reference is made to the legend of Noal's having planted the cedars, from the wood of which the ark was afterwards built. The rock upon which the Church is built (Matt. xvi. I 8 ) is explained to be 'the body wherewith the Lord was clothed' ; and the 'gates of hell' or Hades, to be 'the gates of Sheol,' which could not retain Christ. 'It is our Lord Jesus, the Messiah, who goeth down amongst the dead, and hath lordship over death, and cutteth the bands of Sheoll, and breaketh the bars of iron and leadeth captive captivity, and goeth up in glory.' In plain words, 'the Rock' is declared to have been 'the Messiah,' and Rom. ix. 33, with the quotation there made from Isaiah, are referred to in proof. The drinking from the rock noticed in I Cor. $\mathbf{x} .4$ is also brought in here. The fact that Peter was 'convicted of fault' by Paul his colleague, is adduced to prove that Peter was not the rock; and several other passages are rather unfairly pressed against Peter. All this proves clearly that the homily was written mainly with the object of controverting the Petrine claims.

\section{H. H. WRIGHT.}

Liverpool.

\section{(Paul's ' Mhissionary Эournęs.'}

THE expression 'missionary journey,' used of the movements of Paul, seems inappropriate and to some extent misleading. From the date of his conversion Paul was consecrated to a missionary life among the Gentiles. How many tours or journeys it implied, who shall reckon? The so-called first missionary journey has something of a tentative aspect. It seems as if it were an experiment, or something that might be regarded apart from the regular current of his life. Christian leaders at the time were moving boldly, but more or less blindly, under the guidance of the Spirit. But to us it is clear that Paul's own plans and purposes were definite enough. Nor was this first journey really the first. $\mathrm{He}$ had already evangelised parts of Cilicia (Acts xv, 23), and probably parts of Syria (Gal. i. 2 I).

The Council of Jerusalem is from an external point of view a dividing line across the middle of Paul's active life. Then and thenceforward he was recognised by the authorities as a missionary apostle. Superficially, therefore, his life appears in two halves, one before and one after this event. But to himself he was an apostle from the first, and his career is a unity from Damascus to Rome.

The distinguishing of the second and third missionary journeys is based on the supposition that Antioch was the headquarters of Paul, and the centre of aggressive Christianity. Once, returning from Jerusalem, the apostle turned aside to see old friends at Antioch. This flying visit, of which nothing is recorded, is elevated into a dividing mark. The point is important only in its bearing on our conceptions of historic facts. I am of opinion that one of the chief results of the Council was the formal recognition of Jerusalem as the metropolis and authoritative home of Christianity; and that in no sense could Antioch, after that meeting, be regarded as a place at which Paul or any other evangelist had to report himself. The division into missionary journeys assumes the contrary, but it also obscures the true view of the life of Paul. To the Church Paul is simply a great 
doctor ; first a dogmatist and, secondly, a religioethical teacher. To himself he was one thing only-a missionary, whose work it was to preach the Cross so as to found churches in all lands, and to be in all things the slave of his Master.

\section{Wilson College, Bombaj'. \\ (ntath and aberak.}

R. Scotr.

Hos. xiv. 8.

In his interesting note on Hos. xiv. 8 in your March number, Mr. Buchanan Blake suggests as a difficulty in the way of accepting Wellhausen's critical emendation and rendering of this verse, that Anath, though well known as a Babylonian and Assyrian deity, is not mentioned by name in the Old Testament as an object of worship to the people of Israel. This difficulty appears to me to be rather apparent than real. Anath, it is true, is not mentioned by name among the gods of the nations into the worship of which Israel frequently fell away, as Baal and Ashtoreth and Molech are; but it may be legitimately inferred, I think, from more than one passage of the Old Testament, that the worship of this divinity was not confined to Babylonia and Assyria, but found its way at an early period to the land of Canaan. In Josh. xix. $3^{S}$ and Judg. i. 33 , we read of a town in the north of Palestine named Beth-anath, i.e. House or Temple of Anath; and in Josh. xv. 59, of another in the southern part of the same land named Beth-anoth. There can be little doubt that both these towns received their names from the fact of having been special sanctuaries or seats of worship of the goddess Anath. Cf. Beth-el (Gen. xxviii. I9, 22), Beth-shemesh (i.e. House or Temple of the Sun, Josh. xv. Io, xix. 22, 38 ; Jer. xliii. I3), Beth-dagon (Josh. xv. 4I, xix. 27). Beth-anath is mentioned repeatedly in the inscriptions of the Egyptian kings of the eighteenth and nineteenth dynasties; it finds a place in the list of towns conquered in Palestine by Thotmes III. of the former, and by Seti I. and Ramses II. of the latter of these dynasties. From the fact mentioned in the Book of Judges that the tribe of Naphtali failed to drive out the inhabitants of this town, it would appear to have been a place of considerable importance and strength-a Canaan- ite stronghold and a sanctuary of Anath at the same time. In all probability, too, the town of Anathoth, the birthplace of the prophet Jeremiah, situated a few miles to the north of Jerusalem, derived its name from Anath (see Robertson Smith, Religion of the Semites, pp. 193-4). He says 'the place-name Anathoth means images of Anath in the plural'; and appeals to this in support of the position maintained by him, that among the Semites several images or pillars sometimes stood together at the same shrine as representatives of a single divinity. We thus see that in the Old Testament, shrines of Anath and seats of her worship are spoken of as existing in at least three different parts of the land of Canaan,-at Beth-anath in Naphtali, at Beth-anoth in Judah, and at Anathoth in Benjamin,-indicating very plainly that her cult must have been at an early period brought from Chaldaa to Canaan, and must have been deeply rooted and widely spread in that country at the time of the Israelitish invasion. Traces of it are met with in Egypt also about the same time. The Tel el-Amarna tablets have recently revealed to us how extensive and profound was the influence of Babylonian civilisation and religion throughout Western Asia and even as far as Egypt during this period, and so help us to understand better the existence in Canaan and Egypt at this early date of the worship of Babylonian deities such as Anath, to which the Old Testament records and the Egyptian monuments alike bear witness.

Another allusion to Anath in the Old Testament may be mentioned in this connexion. In two passages of the Book of Judges (iii. $3 r$ and $v .6$ ) we have reference made to Shamgar the son of Anath, or Shamgar Ben-anath. It is highly probable that the Shamgar referred to in these passages was not an Israelite. His name is not Semitic, but Hittite ; and nowhere else do we ever find an Israelite bearing the name of a heathen divinity, as the father of Shamgar here appears to do. Neither of the two passages which speak of Shamgar requires us to think of him as an Israelite. He does not occupy a place in the regular succession of the Judges; it is simply said that he delivered Israel, which he might have done without being himself an Israelite. Deborah in her song mentions him along with Jael as a helper of Israel in her time of sorest need. Now Jael, as we know, was not an Israelite, and this would rather 
suggest that Shamgar, with whom she is associated, was non-Israelite also. $\mathrm{He}$ may have been a Hittite chieftain who, in alliance with Israel, fought successfully against the Philistines, and whose victory over them might justly be regarded as a deliverance to Israel. Now, in both the passages in Judges in which he is spoken of, this chieftain is significantly called the son of Anath or Benanath. This may be understood in different ways. The most natural supposition would be that Anath was his father's name, and that he received or assumed it in honour of the divinity who was the object of his special reverence and worship. The objection to this view is, that Anath is the name of a female divinity, and therefore not very likely to have been given to or assumed by the father of Shamgar. It has been suggested that

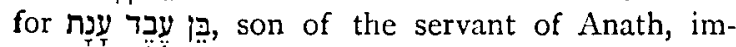
plying that his father had been in some special way consecrated to the service of Anath. This is not at all likely, and perhaps the most probable view is that he was called, or called himself, Shamgar Ben-anath, because, as the head of his clan, he claimed to be directly descended from the tribal divinity. He called himself 'Son of Anath,' just as several of the kings of Syria were named Ben-hadad, i.e. Son of Hadad, the Syrian sun-god. Whichever of these views be adopted, the reference to the goddess Anath remains, and this affurds an additional evidence of the prevalence of the worship of this divinity in Canaan in early times.

In regard to Asherah the question has been much discussed, whether it is ever used as the name of a special divinity, or whether it always denotes the symbol of deity in general in the form either of a living tree or a wooden pole planted beside the altar of the god. The latter view has been very ably defended by Professor Robertson Smith in his Religion of the Semites, and by others. I cannot help thinking, however, that there are several passages of the Old Testament which receive their most natural interpretation, when we understand them to speak of Asheraly as one of the gods of Canaan worshipped by apostate Israelites-e.g. I Kings xv. I 3 (" she had made an abominable image for Asherah'), xviii. I9; 2 Kings xxiii. 4 ('all the vessels which were made for Baal, and for Asherah, and for all the host of heaven '), 7 , etc. And apart from these Old Testament passages, the testimony of the recently discovered Tel elAmarna tablets has made it practically certain that there really was a Canaanitish goddess Asherah, whose cult was firmly established in Palestine at the remote period to which these interesting documents refer. Professor Sayce informs us, in his Patriarchal Palestine, that her name occurs on these tablets in the two forms, Asirtu and Asratu, and we find mentioned as a prominent actor in the scenes described in this correspondence a Canaanite who bears the significant name of Ebed Asherah (Abdi-Asirti), the servant of Asherah. The worship of both Anath and Asherah having thus been common among the Canaanites, it would naturally come to be adopted from them by the Israelites, who, indeed, are frequently charged by the prophets with substituting for the pure worship of Jehovah, or combining with it the impure rites and practices connected with the worship of the gods of Canaan. This removes the chief difficulty in the way of accepting Wellhausen's amended reading and rendering of Hos. xiv. $S$, which gives an excellent sense, and does not require any serious alteration of the Hebrew text. 'Ephraim! what has he to do any more with idols? I, Jehovah, am his Anath and his Asherah. I am like a green fir tree; it is from $\mathrm{Me}$, and not as he used fondly to imagine (see chap. ii. 5,8 ) from Anath and Asherah, that his fruit is found.'

Auchinleck.

JAMES SPence.

\section{Ehe Eraditional Eext of the Tholy Bospels Mindicated and EataB= fished.}

IT has been known for some time that the papers relative to the textual criticism of the Gospels left in an incomplete condition by Dean Burgon at his lamented death in I 888 were entrusted by his executors to the Rev. Edward Miller, with a view to publication. The task of sorting these miscellaneous documents was a very heavy one, and it was found on examination that many of them were but fragmentary, so that they could not be printed without careful and skilled editing. Mr. Miller, who was thoroughly in sympathy with

1 The Traditional Text of the Holy Gospels Vindicated and Established. By J. W. Burgon and E. Miller. (Bell it Sons, i 896. ) 
Dean Burgon's methods of work and with the general conclusions at which he had arrived, has now published a volume made up in part of the Dean's papers, with large additions from his own stores; and for his work every student of the Gospels will be grateful. Its title sufficiently indicates its contents and general tenor. It is a defence of the 'traditional' as opposed to what Mr. Miller calls the 'neologian' text; and it is thus from beginning to end a polemic against the theory of the development of the New Testament text, with which Dr. Hort's name is prominently associated. More particularly, it is an expansion of the arguments used by Dean Burgon in defence of his opinion that the two oldest Greek codices, the Vatican and the Sinaitic ( $B$ and $N$ ), far from preserving the text in an exceptional state of purity, were two of the most corrupt manuscripts in existence. We cannot here go into details, but it will be familiar to readers of THE Expository Times that Dr. Hort held that four types of text might fairly be distinguished, the 'neutral,' or nearest to the apostolic autographs, which is best presented in $\mathrm{S} \mathrm{B}$ and the Egyptian versions; the 'Western'; the 'Alexandrian'; and the 'Syrian,' this last being found in the later uncials, and in nearly all the cursives.

Dean Burgon and Mr. Miller object to this nomenclature, and maintain that the last type of text is the purest of all, and that it ought not to be labelled as 'Syrian.' Of the arguments that are advanced in the volume before us, we can only notice one or two here. And first, an argument upon which stress is laid is this. It is admitted that the 'Syrian' text has been 'traditional,' and generally 'received' for I 500 years. Now, these fifteen centuries are said to 'involve the other centuries that had passed previously, because the Catholic Church of Christ is ever consistent with itself, and are thus virtually decisive of the controversy' (p. 94). This argument is appealed to more than once, but we fear that it will not carry conviction to many. Bentley saw the hand of Providence in the providential preservation of the substance of the record, so that doctrinal questions are little affected, no matter which of the competing readings are adopted. And we might well agree with this; we might even go further, and say that it was impossible to suppose that the true text of the New Testament should ever be lost to the Church, just as it is impossible to suppose that there would be an absolute and complete apostasy of Christendom from the cardinal doctrines of the faith. But then the phrase, Athanasius contra mundum, reminds' us that at one moment nearly all Christendom was Arian; and it does not seem $\dot{a}$ priori impossible that a similar phenomenon might present itself in the transmission of the text of the Gospels. Why is it absurd to hold that Codex B and its adherents, though few in number in some passages, should yet retain a true reading corrupted in the vast majority of manuscripts? The question cannot be decided by considerations of this kind; it is entirely a question of evidence. If we were going to argue $a$ priori on the subject, we could make out a strong case for the impossibility of so precious a gift to mankind as the record of the words of our Lord being ever impaired by the carelessness of scribes, for the impossibility of there being any variant readings at all.

But there is a great deal in the book before us of serious argument $a$ posteriori, as well as this; and it must be reckoned with. There is a long chapter on the testimony of the Christian writers before 400 A.D., in which a direct attempt is made to overthrow Dr. Hort's general contention as to the comparatively late appearance of what he called the 'Syrian' form of text. Mr. Miller has selected some thirty passages from the Gospels, and has printed the patristic testimony for and against the Textus Receptus in each case; and he claims to have shown that the balance of evidence is on the side of the 'traditional' as offered to the 'neologian' readings. We will confess at once that, having gone through the references in question, we are not satisfied that he has made out his case. In the first place, in two of the passages selected, Dr. Hort's text agrees with the Textus Receptus; so that they may be left out of account. In the next place,-and this is more important,-Mr. Miller's argument seems to be that if he can find good evidence before the middle of the fourth century for distinctively 'Syrian' readings, Dr. Hort's elaborate edifice falls to pieces. But Dr. Hort never said that no third or fourth century evidence could be produced for these readings. What he did hold was that this form of text did not become dominant until the middle of the fourth century, and that no sure traces of it could be detected before the middle of the third (Introd., p. I 14 ). So that by far the larger part of Mr. Miller's citations, 
if applied ad hominem with reference to Dr. Hort, prove nothing; they are in many cases given by Dr. Hort himself in his famous Introduction. And then, though in a work so full of details as this, no reasonable person will expect infallible accuracy, some of the evidence is not correctly cited. For example, in the case of Matt. ix. I3, the additamentum eis $\mu \in \tau$ ávorav is not found in the passage of the Epistle of Barnabas, to which Mr. Miller appeals. And it is by no means plain in the same case that Origen and Irenæus, in the passages cited, are quoting from St. Matthew or St. Mark; it is not possible to prove that they have not Luke $v, 3 I, 32$ in their minds, where everyone admits the words to be genuine. Or again in the famous variant in the Gloria in excelsis (єvंסokia or

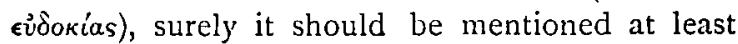
that Origen most distinctly witnesses to the latter reading in a passage cited in more than one text-book. But, although for the reasons we have given, we are not satisfied that the appeal to early patristic testimony is favourable to the Textus Receptus, no one can have anything but welcome for a full discussion of the whole question. The character of $\mathbf{N}$ and $\mathrm{B}$ is perhaps not so bad as Dean Burgon would have had us believe; but it may well be that as we learn more about the history of their origin, we shall have to treat their evidence with somewhat less respect than has been customary of late years.

We have left ourselves no space to speak of the important chapters on the witness of the Syriac and the Latin versions, or of the interesting and, in some cases, valuable appendices with which the book concludes. We hope that it may be widely read, and that it may stimulate fresh independent study in the region of textual criticism.

\section{J. H. Bernard.}

Dublin.

\section{$\longrightarrow$ \\ Ehe dostolic Bospe?.}

Mr. Blair says his book is the outcome of "the labour of many silent years.' We can well believe it. To have written this book of 393 closely-

1 The Apostolic Gospel, with a Critical Reconstruction of the Text. By J. Fulton Blair, B.D. (London: Smith, Elder, \& Co.) printed pages, in most of which some delicate question of criticism is handled and a definite conclusion reached, must have been no ordinary undertaking. And it is due to say at once, the more so that we differ from Mr. Blair on many of his conclusions, that we appreciate not only the great labour, but also the critical honesty which his work displays; and that in our opinion he has laid students of the Gospels under a large debt of gratitude.

Mr. Blair, however, might have made the form of his book more attractive. In truth, it almost takes the heart out of one to read it. The subject no doubt is difficult, and could hardly offer easy reading; but if the long paragraphs had been broken up and their arguments summarised or indicated on the margin, the reader's patience would not have been so severely tried.

The subject of this book must, of course, be largely a matter of conjecture; and in dealing with it the dogmatic spirit is wholly out of place. We are not sure that Mr. Blair, though he disclaims to have reached finality, has always been sensible of this; but in this respect much allowance ought to be made for one who, like the author, has given his whole strength to his subject, and has naturally formed somewhat definite views.

The purpose, as the title indicates, is to discover the original Apostolic Gospel, whose existence, it is affirmed, is established, either as an oral tradition or a written gospel, by the fact that Matthew and Luke "contain parallel incidents and logia which have not been borrowed from Mark' (p. 3). For wider reasons than this, we should be disposed to urge the existence of this original Apostolic Gospel. It was in the nature of things that some such Gospels should be the material of apostolic preaching. The Synoptic Gospels were the results, and not the foundation, of this preaching. 'The primary Gospel was proved, so to speak, in life, before it was fixed in writing. Out of the countless multitude of Christ's acts, those were selected and arranged during the ministry of twenty years which were seen to have the fullest representative significance for the exhibition of His divine life. The oral collection thus formed became in every sense coincident with the "Gospel"; and our Gospels are the permanent compendium of its contents' (Westcott, Intro- 
duction, pp. I 7o, I 7 I). Manifestly the reconstruction of this apostolic source is, as Mr. Blair says, 'at the present day the first problem of gospel criticism' - a problem demanding so much delicate perception that theologians assume inevitable failure (p. 4).

How then is this original source to be restored? In his introduction Mr. Blair unfolds the principles upon which he has proceeded. And here, we think, he has failed somewhat in clearness. We understand his first two principles, namely-(I) that there are narratives in Luke which do not owe their position to the motive of edifying readers, but are new starting - points, which it may be conjectured had a place in the original source (p. 9); and (2) that additional details, not taken from Mark may be regarded, should their position be not otherwise explainable, as constituents of the apostolic source (p. I I). But his third and fourth principles, which deal with the sequence of the narratives, we confess we do not follow; and we cannot but believe that this work would have gained much had the broad principles which underlie the argument been set forth so as to make them more easily grasped, and more securely retained.

In the text of the Apostolic Gospel, according to the author's views, more is certainly included than we expected to find. Beginning with the preaching of the Baptist, it comprises, among other things, the Baptism of our Lord, His Temptation, a portion of the Sermon on the Mount, various miracles-e.g. the healing of the centurion's son, raising of the widow's son, stilling of the storm, the mission of the Twelve and their return, various dealings with pharisaic righteousness, the enunciation of the kingdom and its requirements, the ecclesiastical and civil trial, the crucifixion, the burial, and it closes with the empty tomb (Luke xxiv. 12). "The memoir thus gained is chronological. It agrees in outline with the Fourth Gospel; it enables us to distinguish the constituents of the second ; it reveals the origin of the first and third ...'(Preface).

The main portion of the book consists of ' $a$ critical reconstruction of the text'-in reality, of course, a vindication for the inclusion or exclusion of particular portions of the Gospels. It is impossible to follow Mr. Blair, or do justice within the limits of this review to the laboured and valuable analysis which he offers; but it is right to say that he claims to be more conservative than others who have preceded him in this field. The general conclusion he reaches regarding the whole question is that the 'apostolic source, which existed at first as an oral tradition, was committed to writing at different places by different men to meet the requirements of the Christian Society, that Mark is a combination of the versions'; and that 'the Fourth Gospel is . . . an elaborated version of the apostolic source.' $\mathrm{He}$ declines to accept 'the conmon assumption that the Synoptic problem is altogether distinct from the Johannine.' He believes, in short, that 'the four Gospels are simultaneous equations, that the unknown quanity is the apostolic source, and that the value of $x$ can be discovered' (pp. 16, r 7 ). Mark's Gospel, it will be observed, is held to be a 'combination of the versions,' and its Petrine origin is rejected. Indeed, Mr. Blair is prepared to prove -'by arguing, of course, from probabilities'-that the Second Gospel is a primitive harmony, and not a recollection of the preaching of Peter. Nevertheless, we do not think he has invalidated what Westcott calls ' the most important testimony' of Papias.

$\mathrm{Mr}$. Blair has evidently a very poor opinion of the historicity of our Lord's recorded appearances after His resurrection. 'They are like the tinted clouds of the evening sky, fugitive, uncertain, illusory.' 'The evidence is distinctly in favour of the conclusion that the Galilean manifestations are unhistorical' (pp. 389,390 ). He contemptuously tosses to the 'theorists' the business of reconciling the accounts, and remarks that when they have done so 'they will deserve some attention.' But really Mr. Blair is very much of a 'theorist' himself ; and we venture to submit to him the desirability of addressing himself to the problem in a less arbitrary frame of mind than his closing pages manifest. Far from thinking the Apostolic Gospel would close with the bare account of the empty tomb, we should $a$ priori expect that apostolic preaching, being the powerful force it became, would have a good deal to say regarding those post-resurrection appearances, which manifestly were an intense reality to the apostles themselves as they have since become the undying springs of the finest Christian experience.

\section{G. Elmslie Troup.}

\section{Broughty-Ferry.}




\section{St. (paul and 畐eath.}

Students of St. Paul's epistles cannot fail to be struck with the frequency with which the great apostle speaks of death and dying. But when he uses these words it is not to refer so much to the physical act, the separation of body from soul, as to the more serious and awful condition, the separation of the soul from God. And it is specially worthy of notice that when he has to speak of his own death, or that of believers, he prefers to employ some other word or phrase, which to the ear and heart sounds less dreadful than the grim word death.

In connexion with this subject there are more than sixty passages to be considered-a conjunct view of which, we believe, justifies us in making this generalisation, that death to St. Paul was awful, horrible, a thing to shrink from, and to dread. Hence it is that if he wishes to show what a calamity it is to be out of Christ, he calls such a condition death. To be carnally minded is death. The wages of $\sin$ is death. The sorrow of the world worketh death, etc. Or if his aim is to set forth the privileges of being in Christ, he speaks of being free 'from the law of death,' 'delivered from so great a death,' 'death shall not separate,' etc. When he considers the greatness of Christ, the magnitude of His work, it is with splendid emphasis that he speaks of $H i$ is death, He died. That death, too, hath abolished death. The believer can now exclaim, ' $\mathrm{O}$ death, where is thy sting?' In other passages Paul speaks of the reign of death, of denth as the last enemy, and otherwise shows that to him even the thought of death was overwhelming and awful, enough to take all the joy out of life had not Christ died. It is to be noted, too, that the much-discussed text, 'If in this life only we have hope in Christ, we are of all men most miserable,' occurs amid the matchless sentences of I Cor. xv., where he deals with the splendid consequences of Christ's death and resurrection, making specially prominent the victory over diath. And then when the apostle faces death, either in thought or reality, he will not, even by using the word, make the slightest concession to the enemy. If he dies, it is to the Lord. To die is gain, to fall asleep, to be offered, to depart, to finish a race with joy. It is not really death. Christ has suffered that. The Christian falls asleep. "If we believe that Jesus died and rose again, even so them also which sleep in Jesus will God bring with Him.'

From such quotations, only a few out of the many that could be given, we can gather that before his conversion St. Paul had probably an almost superstitious fear of death, - a common symptom in men who breathe out slaughter, - and when old things passed away and all things became new, the fear was not forgotten. It deepened, however, under God, his insight into the greatness of salvation, and added force to many a noble argument based on the atoning death of Jesus.

Borgue Manse.

\section{James Bell Henderson.}

\section{Thebren Concordancer.}

THE statement of Mr. Lukyn Williams, on p. $36 \mathrm{I}$ of your last issue, that prior to the appearance of Mandelkern's Hebrez' Concordance that of Fürst was 'far the best,' ought not, I think, to be allowed to pass unchallenged. Benjamin Davidson's Concordance, published by Bagsters (my copy bears date ${ }^{2} S_{7} 6$ ), is both far more convenient than Fürst's (it is a large-sized octavo) and decidedly more accurate. It is mentioned and praised by Mandelkern himself (p. vii). I do not wish needlessly to depreciate Fürst's work, which can only have been completed, as he says himself in his preface, exantlato incredibili labore; but the fact remains that, by whatever means, Davidson produced a more trustworthy work. Certainly Fürst, by giving longer explanations of the meanings of words, and by various appendices, put more into his work than Davidson did; but much of this additional matter is of slight value, and none of it belongs properly to a 'Concordance ' at all. Since I first learnt of Davidson's Concordance I have entirely discarded Fürst ; and I still use the former for all ordinary purposes, merely employing Mandelkern for the particles and proper names. The chief defect in Davidson (which, however, is equally a defect in Fürst) is that in the particles which he does include, the occurrences are often not

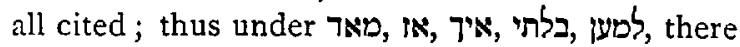
are several omissions, and under בית a great many. The Hebrew student who does not care to spend $£ 7$, tos. upon Mandelkern's stately work, may, 
however, easily supply these deficiencies for himself with the help of G. V. Wigram's Hebraist's Vade Mecum, is67 (also published by Bagsters), which gives in full (but without transcribing the passages) the occurrences of cvery Hebrew (and Aramaic) word (including even such words as and $ל$, and all proper names) found in the Old Testament. It is incorrect, therefore, to say that until the publication of Mandelkern's work, 'one had to turn to Noldius' for the particles. In a notice at the beginning of Davidson's Concordance it is said that the accuracy of the work is largely due to its having been verified throughout by the editor with the Hebraist's Vade Meam. The merits of these two works, in which English scholars have shown that they can compete with (and even excel) their German brethren in completeness and accuracy, are such that it is, I think, matter of regret that they are not better known to students than seems to be the case; and hence I am very glad to have this opportunity of mentioning them. ${ }^{1}$ I have sometimes wondered that it did not occur to the publishers of Davidson's work to increase its utility by publishing a short appendix containing the omitted passages referred to above, and also including a Concordance of some of the more

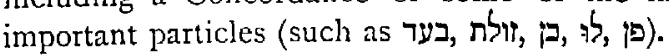

As regards Mandelkern's work, I am naturally not at present in a position to affirm, from my own use of it, that it is always accurate; but the greatest care and pains have manifestly been spent upon it ; and assuming that it is accurate, it seems to me, with two exceptions, to be noted inmediately, to contain everything that such a work could be expected to contain, and fully to come up to the ideal of a Concordance. Emendations of the Massoretic text do not appear to me to have any place in a Concordance: they belong to an edition or Commentary of the text, to a translation, or (in certain cases) to a Lexicon, but not to a Concordance. Mandelkern gives (I), P. I-I253, all the matter found ordinarily in Concordances, together with the occurrences of many particles not contained in other Concordances (as yֵ, alone and with suffixes, מה (alone only),

1 The use of the Vadi Mecum, by Stade and Siegfried, would have enabled them often to avoid inaccuracies in their statements respecting the occurrences of particles : thus in occurs not ' 8 ' times in II Isaiah but 23 times; and there בל ! all, etc.

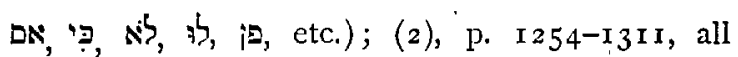

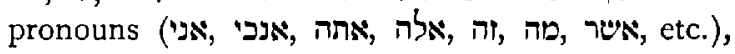
alone and with prefixes; (3), p. I 3 I $2-1348$, all Aramaic words; $(4)$, p. I349-I532, all proper names (with passages transcribed in full). The value of having the particles, with the contexts transcribed, can hardly be exaggerated. The pronouns are placed by themselves at the end,presumably, because the author, after he had begun to print, extended his original plan; otherwise, it would have been more convenient to place them in the alphabetical order in the body of the work. There are also some inconsistencies in the manner in which they are treated : for instance, we find $m$ in the body of the Concordance, ממנו, מטנה, and among the pronouns in the appendix, but מטכך, מספר, etc., nowhere at all ; the case is similar with במוך. We find in the appendix,

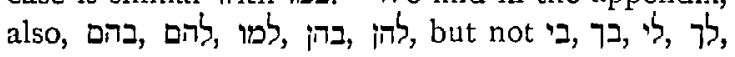
etc. The occurrences of $\mathrm{N}$, with, are not given at all, either alone or with suffixes. These irregularities of arrangement are, no doubt, quickly learnt by practice; but certainly the volume would have been improved, had $\Omega$, with, (alone and with suffixes), and $2, J$, and $\zeta$, with suffixes, been given in full (which, to judge from the space taken by them in the Hebraist's Vade Mecum, would not have occupied more than a few pages), and arranged in their proper places in the body of the Concordance. To transcribe the occurrences of $\pi \mathrm{s}$, the nota accusativi, would of course have been simple waste of space. Dr. Mandelkern enumerates the verbs with which it is construed, and also gives a useful select list of passages in which its use is anomalous. The arrangement of a work of such magnitude cannot, of course, now be altered; but perhaps at some future time Dr. Mandelkern might think it worth while to extend the part devoted to pronouns in his monumental work by including in it the particles with pronominal suffixes which are at present omitted.

Christ Church, Oxford.

S. R. Driver.

Printed by MORRIsON \& GibB Limited, Tanfield Works, and Published by T. \& T. CLARK, 38 George Street, Edinburgh. It is requested that all literary communications be addressed to THE EDITOR, Kinneff, Bervie, N.B. 